\title{
CREATING A PATRIOTIC HISTORY: HISTORICAL SOURCE-EDITING AS NATIONAL MONUMENT
} society for the publication of manuscripts on Scandinavian history], a society dedicated to the editing and printing of historical source documents, was founded in Stockholm in 1815 . Earlier research has focused upon the editorial praxis of the society's publication, Handlingar rörande Skandinaviens historia. Here I focus more upon the monumental and museological aspects of the society's work. Viewed as types of national monument, source editions from the romantic era can tell us something about how history was produced and popularised during this period. The source documents printed in Handlingar served as educational tools intended to help the reader better understand history, specifically in this case the history of Sweden. But such editions also functioned - like a museum or a monument - as triggers for emotions, memory, and historicity, and like those other institutions, romantic-period source editions played a significant role in the construction and negotiation of national memory and heritage. ${ }^{1}$
}

K EYW O R D S Popularisation, History, Nationalism, Source editing, Monuments, Heritage, Memory

\section{Creating a Patriotic History: \\ Historical Source-editing as National Monument}

On 10 November 1815, a group of men gathered in the rooms of the Marshal of the Realm in the Royal Palace at Stockholm. The group was made up principally of aristocratic politicians, formally led by the Minister of Foreign Affairs, Count Lars von Engeström. The rest of the group consisted of the Secretary of State Baron Gudmund Jöran Adlerbeth; the lawyer, politician and chamberlain to the late queen dowager Axel Gabriel Silfverstolpe; and the chief chamberlain to the late queen dowager Baron Adolf Ludvig Stjerneld. Also present was Adlerbeth's son, Jakob Adlerbeth, an aspiring antiquarian and official; the registrar at the $\mathrm{Na}$ tional Archives (Riksarkivet) Olof Sundel; and the historical author and publicist Per Adolf Granberg. These men founded what they called the 'Kommittéen för 
utgifvandet af handskrifter rörande Skandinaviens historia' [Committee for the printing of documents concerning the history of Scandinavia] with the intention of printing historical source documents under the heading Handlingar rörande Skandinaviens Historia. ${ }^{2}$

How are we to understand this project? I will argue that the main objective behind the creation of this society was to make a kind of national monument, very much in line with the kind of built monuments erected at the same time, like the Walhalla in Germany, the Pantheon in Paris, or the many national museums and galleries that were founded during the first half of the nineteenth century. Historical source editions function as printed national monuments, whose demarcations in time and space, much like the work of national museums, are part of the construction and negotiations of national memory and heritage. Like national museums, such editions are claiming, articulating, and representing dominant national values, myths, and realities. ${ }^{3}$

Analysing the role played by the editing of historical source documents in the construction of national histories during the early nineteenth century is a comparatively recent field and historical source editions like the Monumenta Germaniae Historica, the Documents Inédits sur l'Histoire de France, the different national Diplomatarium-editions, or the Handlingar rörande Skandinaviens Historia, have yet to receive the detailed scholarly attention which they deserve. Previous scholarly work has tended to focus on the editing of literary texts and the (broadly similar) role which such editing played in the creation of nation states in the nineteenth century. ${ }^{4}$ Source editions such as those just mentioned have, by contrast, often tended to be understood as scholarly tools not intended to be read by anyone other than historians and philologists. Hence work remains to be done to establish the relationship between such source editions and other, comparable contemporary practices of nation-building, such as the construction of museums and monuments, and the creation of a canon of national literature. It is in this context, i.e. as part of the process of creating a Swedish national history, which I intend to consider the Kungliga Samfundet and its Handlingar. The primary purpose of the society, I will suggest, was to create a popular textual monument of the nation which was to be distributed to, and read by, what the editors perceived as wide circles of society. ${ }^{5}$ This process of creating national histories took place prior to the professionalization of history as an academic discipline in the late nineteenth century and involved collaboration between various groups, including young academics and older, aristocratic politicians of the ancien régime. It also involved a new sense of history and I shall also examine how the Kungliga Samfundet and its Handlingar were dependent upon this new understanding of history ${ }^{6}$ 


\section{Creating a Society for the Printing \\ of Historical Source Documents}

The idea for a society to print historical source documents came from Stjerneld who had since 1810 tried to raise funds for different antiquarian efforts. In 1814 he asked for, and received, instructions (written by himself) and a small grant from the state to take inventory of ancient monuments and antiquities in the Swedish countryside. One of his actions during 1814 was to publish an advertisement in Inrikes tidningar, the government newspaper and gazette of Sweden, asking anyone who owned documents that 'röra Nordiska antiqviteter, eller af perma-bref och andra forntida handskrifter' [touched upon Nordic antiquities, or of parchment letters and other ancient manuscripts] and wanted to sell or donate them for preservation to contact him, and he would in turn give notice to the King.' 'The King' should probably be interpreted here as the Royal Swedish Academy of Letters, History, and Antiquities, which was the authority responsible for questions concerning heritage. Stjerneld seems to have started thinking about the idea of collecting and/or printing handwritten documents as a means of preserving them for posterity during the spring of 1815 , and he seems also to have discussed the issue with interested parties among the courtiers, politicians, historians, and civil servants from the National Archives and other relevant bodies.

In July 1815 , Stjerneld took action and sent a letter to the King and the royal family. In the letter he argued that there were many historical source documents in private hands which were close to destruction and in need of protection, and that the proper way of doing this would be to transcribe, print, and deliver them to the public. His suggestion for how this might best be done was to create a committee comprising high ranking state officials with historical knowledge and persons with special expertise about historical documents: for a period of three years, this committee should find, select, and print a series of volumes containing historical documents. To this end, Stjerneld says, he needs royal support, both morally and financially. ${ }^{8}$ To underline his credibility, he mentions several officials as well as historians with whom he had already consulted and who have agreed to help him with the selection of proper documents to print, amongst them most of the persons present at the inaugural meeting of the committee in November that same year.

The project received the royal support Stjerneld had sought. King Charles XIII promised to give 300 Riksdaler each year for a period of three years; Queen Charlotte promised 100 a year; the Crown Prince Charles John (Bernadotte) 200 a year; and his son Prince Oscar another 100 per annum. These royal donations of 700 Riksdaler per annum for three years made up the mainstay of the project, both financially and morally. With royal backing, Stjerneld had little difficulty finding other subscribers for the project. By using his personal network as well as sending requests to all the bishops in the country, Stjerneld raised a total amount of 8,400 Riksdaler for the first three years. Most subscribers, who were promised 
a copy of all publications made in the period, gave 10 Riksdaler each, although some gave between 20 and up to 50 per annum. ${ }^{9}$ During the following years, the committee was consolidated and formalised as the 'Kungliga Samfundet för utgivande av handlingar rörande Skandinaviens historia' [Royal Society for the printing of documents concerning the history of Scandinavia] and ranked as one of the Royal Academies.

Attempts similar to the Handlingar rörande Skandinaviens Historia followed in other countries, with this kind of initiative common in the post-Napoleonic era. In the German states a group of aristocratic politicians - very much like their Swedish counterpart - led by the former Prussian Minister Baron Karl vom Stein, formed in 1819 the 'Gesellschaft für ältere Deutsche Geschichtskunde' [Society for the study of older German history], with the ambition of editing and publishing historical documents in a scholarly manner, under the title Monumenta Germaniae Historica. ${ }^{10}$ Historical source editions seem to have been discussed in most countries even earlier, and in some cases also realised, as in Italy, where Ludovici Muratori published medieval chronicles under the heading Rerum Italicorum scriptores between 1723 and 1751, and in Denmark, where the historian Jakob Langebek edited a similar work, Scriptores rerum Danicarum medii avi [Danish writers of the middle ages], between 1772 and $1774 .{ }^{11}$ These works were never institutionalised, however, and were dependent upon a single person. After 1814, though, efforts were made in several states to establish institutional structures that could assume a long-term responsibility for printing what were perceived as invaluable historical source materials in both private and public archives. Private individuals were responsible for many of the projects, but in most cases state support was sought and often received.

The majority of these projects, like Kungliga Samfundet or the Gesellschaft für ältere Deutsche Geschichtskunde, functioned as a kind of 'collective collector. ${ }^{12}$ The societies published documents from the collections of their members, thereby creating new collections comprising the published documents. In this way, the old aristocratic practice of collecting historical documents was given a new form that could be interpreted as a national and patriotic endeavour.

In 1823, the Gesellschaft für älter Deutsche Geschichtskunde published the first volume of Monumenta Germaniae Historica, consisting of historical source documents from the reign of Charlemagne, and more volumes were to follow, divided into the subcategories of Scriptores, Leges, Diplomata, Epistolae, and Antiquitates. The work was not carried out by the aristocrats of the board, however, but by scholars whom they appointed, and to aid the board, connections were also made with leading scholars and academics like Goethe, the brothers Grimm, and the historians of law Karl Friedrich Eichhorn and Friedrich Carl von Savigny. ${ }^{13}$ In France the even more-wide ranging project, Documents inédits sur l'bistorie de France [Unpublished documents on the history of France], began in the mid-183os with the staggering ambition of collecting and printing all source material relating to French history. ${ }^{14}$ As with their German and Swedish counterparts, they are still active today. In Great Britain, a 'Historical Manuscripts Commission' was founded in 1859 under similar circumstances. ${ }^{15}$ 


\section{Popularisation and a New Sense of History}

When making his appeal to the royal family in 1815 , Stjerneld argued that:

Vi hafva hos enskildte, skatter af gamla och nyare handskrifter, nära förstöringen, hvilka visserligen till en stor del böra bevaras genom deras tryckning: Det är alltid högst nödigt för historian, att tidernas gömda förråd framlemnar med sanningen till allmänt bedömande.

[We have in private hands, treasures of old and new manuscripts, which are in poor condition and should, therefore, in most cases be preserved by printing them: It is always of high historical importance, that the truth be brought forward to the public eye from the hidden storage of time. $]^{16}$

Two things are of special interest here. First, the idea that something needs to be saved. This kind of rhetoric of saving something that is threatened with imminent destruction was common in antiquarian circles during the romantic period. It is not always clear though what really was threatened. As Susan Crane noted in her study of the German antiquarian societies of the early nineteenth century, most heritage sites in the German countries had been damaged not during the Napoleonic Wars, but rather centuries earlier during the Thirty Years' War, and the documents of different church or private archives were not in any greater danger of falling apart than they had been a decade or two earlier. What was at stake, therefore, was not the physical objects so much as something else: the objects as enablers of emotions, memory - and historicity. ${ }^{17}$

The sense that historical monuments, documents, and other kinds of memorials were under threat has to do with the emergence of a new idea of history and historicity. The French Revolution and the Napoleonic Wars gave rise to a new world order which in turn created a feeling of loss - a loss of roots and a loss of tradition which had somehow to be bridged - out of which arose the idea of preserving history and its objects. The possibility of interpreting an object as historical was therefore less dependent upon the age of the object than upon its potential for provoking a sense of history in the observer. But in order for this to be possible, a qualified individual - a historian, an antiquary, or a collector - was required to place the object in a context and thereby inscribe meaning upon it. This could be done by, for example, putting an object in a collection or a museum, or by transcribing and printing a document, or by publicly announcing that a ruin, a monument, or a place, is a site of heritage, a memorial. ${ }^{18}$

The second point of interest in Stjerneld's appeal is the idea that the documents should be brought forward to the public. This shows us how the printed documents were intended to be viewed. As printed transcriptions of historical originals, the documents presented in the volumes of Handlingar rörande Skandinaviens Historia were copies, much like the plaster casts of antique sculpture that were popular in art collections and museums during the same period. ${ }^{19}$ By print- 
ing the transcripts in the series, the documents were attested to be of historical interest, but at the same time the Kungliga Samfundet left the interpretation of the documents to the reader. As in a museum, the objects were presented as part of a historical context and as objects with historicity, but the interpretation of this historicity was left to historians, or to the public.

In his letter to the king in 1815, Stjerneld gives two main reasons for the need to print historical documents, beyond merely saving them from decay. Firstly, it is for the historians who need sources to work with: 'må historieskrifvarn begagna dessa ämnen, liksom Skalden fordomdags' [may the historian use these materials, like the Poets of the past]; secondly it is 'högst nödigt för historian, att tidernas förråd framlämnar med sanningen till allmänt bedömande' [highly necessary for history, that the hidden storages of time deliver the truth to public judgement]. ${ }^{20}$ The keywords here are 'use', 'judgement', and the 'needed substances' of the statistics (at this time statistics were the science à la mode for understanding society). ${ }^{21}$ These are all active words that imply that the documents were intended to be processed and interpreted by the reader: it was the purpose of the Kungliga Samfundet to familiarise readers with the historical objects and to show how they were to be historicised. In this respect, the Kungliga Samfundet differed from its German counterparts, where the interpretation of the documents was not touched upon. That the learned associations there should in some way change the historical records or rewrite history was perceived as a threat to society by the Prussian and Austrian authorities, and interpretation was therefore never spoken of in connection with objects and printed sources, only the awakening of interest in the objects and the rescuing of the remnants of the past from neglect. ${ }^{22}$

It is also clear from Stjerneld's letter to the king that the intention of the Kungliga Samfundet was not primarily, or at the very least not only, to provide historians with source materials. This was, as mentioned, one of the reasons ('may the historian use these materials'), but more importantly the documents were to be made available for 'public judgment' so that 'history' can bring forward its 'truth'. ${ }^{23}$ It is history rather than the historians which should be served by the printing of these documents. This is further underlined by the King's answer to Stjerneld's letter. On the reverse of the original letter, King Charles XIII writes that he:

underskrifver ... det Project till att förskaffa fler upplysning uti sitt Fäderneslands historia.

[endorse $[s]$... this project to provide more people with information about the history of their fatherland. $]^{24}$

The Kungliga Samfundet seems to have been indebted both to the Enlightenment and to romantic notions of popularisation. The will to make knowledge available to everyone - to popularise it - was a central theme during the Enlightenment, but one that was contested during the years after 1800 . However, what 
the romantic scholars like Fichte, the Grimm brothers, or Friedrich Schlegel wanted was not to write hard-to-understand texts, or to dumb down science, but instead make solid arguments that could be understood by all readers: a kind of argument that made use of evidential images that once seen or understood could not be questioned again. ${ }^{25}$ In the case of the Grimm brothers, they meant that their Hausmärchen spoke for themselves; the fairy tales were self-evident and their value protected by the fact that they were old and stemmed from the traditional Germanic myths. They too thus worked in a manner similar to that proposed by Fichte. ${ }^{26}$ For the Romantics, the brothers Grimm, and others, literature and ancient documents worked as a form of mental time travel, a bridge between the present and the past. The salvaging and reprinting of historical texts and manuscripts served as a link to the nation's past, to its identity. ${ }^{27}$ The documents of Handlingar worked in a similar way. The reprinted documents should serve as a bridge to history, helping the public to become better acquainted with it.

The pedagogical ambition, and the aim of popularizing knowledge of Swedish history inherent in Handlingar, is also shown by the eagerness of the editors to provide information about periods and persons likely to be less well-known to the public at large. Examples of this practice include the addition to the preface, in the twelfth part of Handlingar, of an explanatory list of the names, and short biographies, of persons belonging to the court of King Magnus IV (Eriksson) who appear in the will of the King and his Queen Blanche of Namur which is printed in the volume. ${ }^{28}$ Another instance can be found in the first volume, when a rudimentary list of names and titles is given in order to make it easier to comprehend a document concerning the Swedish reformation. ${ }^{29}$

The pedagogical ambition of the Kungliga Samfundet is also shown in other ways. In each volume a facsimile of one or more documents was included. The expressed purpose behind this rather expensive addition to the volumes - the technique used was engraving, which was time-consuming and involved expensive materials - was part pedagogical, part patriotic. When at a meeting in December 1816 a parchment letter by King Magnus III (Ladulås, c. 1240-1290) was discussed and eventually approved for inclusion as a facsimile in a forthcoming volume, the protocol contained the following reason: 'för häfdeforskningen skulle vara upplysande om några fac simile af dylika bref, från olika tider, graverades, för att visa stylarnas skiljaktighet under särskilta sekler' [for historical research purposes, if facsimiles of letters like this, from different epochs, were to be engraved, they could be used to show the divergence of writing styles in the different centuries]. ${ }^{30}$ This means that one of the ideas behind including facsimiles of historical documents in the volumes was to show the readers what documents from different eras looked like, so that they themselves could, for example, recognise a thirteenth-century document if they found one. In the long run the reader might even be able to decipher that document, having learnt palaeographic lessons from the facsimiles.

The facsimiles also served another - and more important - purpose. The transcribed and printed documents functioned more as copies of material remains 
of history, where it was not the content of the documents that was significant for the society but who had written it. As printed transcriptions of historical originals, the documents presented in the volumes of Handlingar rörande Skandinaviens Historia were copies, much like the earlier mentioned plaster casts of an antique sculpture. The material aspect of the documents is underscored in the instance of the facsimiles, since in many cases the original documents were more or less unreadable to non-specialists - in several cases a transcript and translation of the document were also printed. ${ }^{31}$ The facsimiles, therefore, allowed the reader in a very concrete way to (almost) hold a document written by for example an admired king in his or her own hand: an act that could act as a trigger for emotion, memory, and historicity. They also made it possible for the subscribers to the Handlingar to own and hold letters written by the famous men who had ruled the nation, to see their handwriting and signature with their own eyes. The printing of the facsimiles added an element of authenticity to the volumes, the facsimiles being as close to an actual historical object as you could come. Together with the rank and the names of the members of the Kungliga Samfundet, the facsimiles strengthened the credibility of the entire project. The careful annotation in the volumes relating which collection a certain document came from, as well as a kind of signature from the society assistant - a position given to aspiring antiquarians in the beginning of their careers - that certifies to the correctness of the transcription, also contributes to this effect.

\section{Distributing the History of the Nation}

Part of the discussion at the first meeting of the Kungliga Samfundet in November 1815 concerned how the publications should be presented. The protocol gives no explanation as to why, but contrary to other similar projects an octavo format was chosen, whereas the different Scriptores and Diplomatarium projects as well as the Monumenta Germaniae Historica chose to use the larger folio. ${ }^{32} \mathrm{~A}$ possible explanation for the use of the smaller octavo format can be traced to when the committee (by then restyled as the Society for the printing of documents concerning the history of Scandinavia) in July 1818 decided that they should send a complete set of the volumes printed - in all, five volumes at that time - to all the gymnasiums in Sweden, as well as to the cadet school at Carlberg. ${ }^{33}$ The smaller format, and the fact that most of the documents printed were in Swedish, suggests that the expected reader was not a scholar, but rather the educated citizen, interested in the nation's history. The octavo signalled seriousness, as opposed to the duodecima of cheap novels, but not the expensive magnificence of the folio format.

It is interesting to note that the protocol speaks about a 'large octavo', which is similar in size to quarto. ${ }^{34}$ When discussing the price of the volume, it was also explicitly stated that it should be 'as low as possible, to promote the proliferation of the work' ${ }^{35}$ The decision to freely distribute the volumes to the gymnasiums likewise points to the more popular purpose of the Kungliga Samfundet. This popular aim of the project is further shown in the response of King Charles XIII 
to the request for support sent by Stjerneld in 1815. In a short sentence, the King provides support for the project, whose aim he says is to 'provide more people with information about the history of their fatherland'. ${ }^{36}$

\section{What Was Published?}

The first 19 volumes of Handlingar rörande Skandinaviens Historia, printed between 1816 and 1834 , contained 461 documents. Out of these, 41 were medieval (that is, written before 1500), 155 from the sixteenth century, 138 from the seventeenth century, and 123 from the eighteenth century. Four titles were not source documents at all, but rather catalogues of manuscript collections belonging to members of the society. ${ }^{37}$ The documents are presented chronologically in each volume, under different headings. The medieval documents are mostly presented as äldre Handlingar hörande till Skandinaviens Historia' [Older documents belonging to the history of Scandinavia], 'Handlingar hörande till Medeltidens Historia' [Documents belonging to the history of the middle ages], or simply 'Gamla Permebref' [Old parchment letters]. ${ }^{38}$ The documents belonging to the modern period, in this case defined as the time after the accession to the throne of Gustav I and the ending of the Kalmar union in 1523, were in turn sorted genealogically after kings and dynasties. The sorting principle is thereby clearly royalist, but also religious (which, given the status of the Lutheran Church of Sweden as the only legitimate religious congregation, also meant patriotic), since all documents concerning the time before the Reformation are presented under the same heading, while postReformation sources are presented in categories that cover shorter time spans made up from genealogical principles. The majority of the documents date from between 1654 and 1718, the so-called Carolingian age, named after the three kings Charles X, Charles XI, and Charles XII. This period coincides with the height of the Swedish Empire and was a period looked upon with both awe and nostalgia during the decades around 1800 . The royalist, patriotic sorting principles are part of the monument-building at work here, whereas the ordering of the documents connects the history of the nation to the history of the monarchy, making a claim that they are the same and interconnected.

\section{The Selection of Documents to be Printed}

The majority of the published documents came from private archives, mostly from archives and collections in the possession of the members themselves, but in some cases official collections like Riksarkivet (The National Archives) were used. When discussing the content of the early volumes, the members of the committee had some problems locating documents of interest, most probably due not just to lack of sources but also because the principles of inclusion and selection had not yet been agreed. It was further concluded that the committee needed to get an overview of the contents of different collections and that they had, therefore, to get hold of inventories of available collections. Apart from us- 
ing their personal networks, they also wanted the bishops to take inventories of the manuscript collections of the country's gymnasiums, but to achieve this it was decided that the bishops should first be invited to become corresponding members of the committee and thereafter asked for the inventories. ${ }^{39}$ This way of getting access to collections by inviting the owners or custodians to become members or corresponding members of the society continued. In 1820, Count Jacob de la Gardie, owner of a large archival collection at Löberöd mansion, was elected as a member of the society, and not long after documents from Löberöd were being printed in Handlingar. ${ }^{40}$

Members would also discuss interesting documents and collections in private, before putting them to the committee at a later stage. In a letter to Lars von Engeström, Stjerneld discusses a series of letters from Charles XII of Sweden that might be of interest to print. The letters were in the possession of Magnus Fredrik Brahe - also a member of the committee - and Stjerneld had made transcriptions of them for Engeström to read and judge their historical value. Stjerneld had already marked the letters he found particularly interesting. Engeström in turn had borrowed a document from Stjerneld's collection for a similar review. ${ }^{41}$ This conversation between Stjerneld and Engeström about documents fit to print in the series continued throughout the 1810 , and this is most likely only one of several similar conversations between members of the group about the subject. ${ }^{42}$

The process of deciding what to print seems to have worked upon an informal scheme, whereby a collection of documents or a single document were made available to the society, either by request of one of the society's members or on the initiative of the owners. The documents were then put before the society at one of the meetings where a quick reading and a brief evaluation of their historical value took place. After this preliminary decision on behalf of the meeting, one of the members was assigned to make a more thorough evaluation and from that a final decision on whether to print or not was made. ${ }^{43}$

\section{History that Bothers: \\ Polishing the Monument}

The selection of material to be printed seems to have been for the most part uncontroversial, with one notable exception which sheds light upon the selection process. When preparing the ninth volume for print, the secretary of the Kungliga Samfundet, the author and official Per Adolf Granberg, spoke out against one of the documents, an essay (and a facsimile of a letter) by the religious author and visionary Emanuel Swedenborg, which he judged to be 'för Nordiska Historien främmande' [foreign to the nordic history]. At a meeting of the Kungliga Samfundetet in October 1821 it was therefore decided that the essay in question should be circulated amongst the members and that everyone's opinion should be heard. ${ }^{44}$ In a document that seems to have accompanied the essay manuscript as it circulated among the society's members, nine delegates have made annotations commenting on whether or not it should be printed. Some voices are 
missing, probably because they were not in Stockholm at the time. All those consulted voted against the printing of the essay except Stjerneld, who merely stated that his opinion had been given during the meeting and need not be repeated; it was most likely he who had wanted the essay printed. However, some found the facsimile to be of value. The harshest critic was the secretary of state, general, and playwright Count Anders Fredrik Skjöldebrand, who claimed:

allt det nonsens den ifrågavarande skriften innehåller, skulle vanpryda Handlingarna till Skandinaviska Historien; och fruktar, att om fac simile infördes, kunde Kgl Samfundet misstänkas att fästa för mycken vigt vid dens namn som författat skriften.

[all the nonsense the essay in question contains, could harm the reputation of the Handlingar till Skandinaviska Historien; and he fears, that if the facsimile were to be included, the Royal Society could assign too much importance to the name of the essay's author.]

In a post scriptum, Skjöldebrand slightly modified his position, suggesting that the essay and facsimile could be included if they were accompanied by a brief remark that the text should be seen as 'ett bidrag till historien om dårskaper som en tid ej varit utan anhängare i norden' [a contribution to the history of follies that had at one time attracted followers in the north]. ${ }^{45}$

Not all delegates were as sceptical about Swedenborg as Sköldebrand, though. Lars von Engeström claims Swedenborg to have been 'en lärd man och en agtningswärd Människja' [man of learning and an honourable man]. However, Engeström explains, like Olof Rudbeck, who was also known in part for his fantastic opinions, Swedenborg 'hörer således till historien' [is known to history] as a 'märkwärdig Swensk man' [meritorious Swede]. Engeström concludes that he thinks that the facsimile should be printed and that the essay should be printed in a shortened version and 'törhända endast på latin' [perhaps just in latin], or with the kind of remark that Sköldebrand had insisted upon. ${ }^{46}$

It is significant that the disputed essay could, in Engeström's opinion, be printed in its original Latin form, but not in Swedish translation. This violates the idea of spreading the historical knowledge to wider circles in an accessible form. The reason for this rather remarkable standpoint is probably that Engeström, as a leading freemason, had Swedenborgian inclinations but found himself unable to argue any further on the matter when all other delegates had already voted against printing the essay. The other two high-ranking masons in the group - Stjerneld, and the politician and courtier Count Claës Fleming were also seemingly much more inclined to print the manuscript than the rest of the group. The suggestion to print it in its original Latin is probably to be seen as a way of trying to save the essay in a printed format, but if printed in Latin it would be inaccessible to all but those whose learning would make them able to understand the text in a specific context and not be misled by it.

This essay never made it to print, but the ninth part of Handlingar rörande Skandinaviens Historia ended with a facsimile of a fragment of a letter by Sweden- 
borg. Right after the table of contents, though, an explanatory text was given, stating that the facsimile of Swedenborg's hand was by:

en Man, hvars vettenskapliga förtjenster alltid skola gifva honom ett utmärkt rum ibland Svenska lärda; men då Kongl. Samfundet icke i härvarande allmänna eller enskilta handskriftsamlingar kunnat finna någon af honom egenhändigt undertecknad skrift, af inskränkt vidd, har det valt att endast införa slutet af ett bref, hvars innehål i öfrigt är fullkomligt främmande för Handlingar rörande Skandinaviens Historia.

[a Man, whose scientific merits will always give him a significant position among Swedish scholars; but since the Royal Society could find no signed manuscripts of shorter length in either private or official archives, it has chosen to print only the end of a letter, the main contents of which are irrelevant to Handlingar rörande Skandinaviens Historia. $]^{47}$

The matter of the Swedenborgian manuscript shows that the members of the Kungliga Samfundet were striving to reach a consensus when deciding what to print. They were also willing to make compromises, either by printing texts they thought were obscure or by allowing texts to be accompanied by explanatory forewords. The episode further shows that nobody wanted an open conflict about the manuscript, but rather that the different sides tried to avoid such a scenario. The Swedenborgian conflict also tells us something about what kind of history the Kungliga Samfundet wanted to disseminate. In their patriotic historical canon, there was no place for a religious deviant, no matter how well-known he was. In this way, the Kungliga Samfundet differs from other national memory projects from the same period, like the National Portrait Gallery at Gripsholm Palace (also invented and curated by Adolf Ludvig Stjerneld) and Biographiskt lexicon öfver namnkunnige svenska män - a dictionary of national biography published between 1835 and 1857 - both of which both included 'bad' examples in their respective canons. ${ }^{48}$

\section{Patriotic and Scholarly Editions}

When the historians of the late nineteenth century were looking back towards the source editions of the first half of the century, not much met their approval, and the editions made by the Kungliga Samfundet were to prove no exception. In an article from 1886 concerning editions of historical documents in Sweden, historian Emil Hildebrand claims that the editions printed in Handlingar were edited 'completely in the mood of the previous century' and that some of the work is a cautionary tale of how such documents 'should not be published, whether you think about the arrangement or the editions'. ${ }^{49}$ This judgment is of course due to the changed standards of academic publishing and the ongoing professionalization of historians during the nineteenth century. Yet as we have seen, several of the most prominent historians of the time were involved in the editing of Handlingar. Initially, this was as advisors and suppliers of material, but as com- 
munication between Uppsala and Stockholm continued to improve, especially after steam boat lines began in the 1820s, the number of professional historians like Erik Gustaf Geijer and Johan Henrik Schröder who became involved in the actual editing increased. And even during the early years of the society, the involvement of historians like Eric Michael Fant and the archivist Olof Sundel meant that the society had some knowledge of the scholarly principles of the day. It is interesting to note that among the participants there are no philologists (with one exception). Neither Adolph Törneros nor Wilhelm Fredrik Palmblad both Classical philologists working in Uppsala - participated in the work. ${ }^{50}$ The exception among the society's members was Secretary of State Baron Gudmund Jöran Adlerbeth who, apart from being a poet, had also translated Virgil into Swedish and, inspired by the German Neuhumanismus, campaigned for ancient Greek to be included in the Swedish school curriculum. ${ }^{51}$

Even though the publications of the Kungliga Samfundet did not always reach the standards demanded by the late nineteenth-century editors, this does not mean the society had no idea about proper scholarly editing. It is also important to keep in mind that the foremost reason for the society to print historical documents was not scientific or academic, but rather educational and nationalistic. Scholarly ambitions obviously existed, but they were not the most important. The first volume of Handlingar rörande Skandinaviens historia was - partly because of a lack of documents to print - rather fragmented. ${ }^{52}$ But by the second volume there are signs of efforts to thematise the editing. One of the leading principles of the first two decades of editing and printing seems to have been to present documents from a long chronological period in every volume. Documents ranging from the sixteenth to the eighteenth centuries are present in every volume, and it is clear that the editors have further tried to find some medieval manuscripts to print in each volume, but failed in some cases. The second volume starts with the, for this period, rather typical selection of seemingly random letters between important persons, but ends with two thematic collections of documents: one about the Rising of the Dalesmen in 1743, a peasant rebellion against the parliament in the aftermath of the war with Russia 1741-1743, and the other about the aftermath of the same war and the execution of the general Carl Emil Lewenhaupt. ${ }^{53}$ These two themes also continued in the next volume. ${ }^{54}$

This manner of printing documents thematically continued and in the fourth volume a long section was dedicated to the so-called Sture-murders, when King Erik XIV assassinated three members of the powerful Sture family at Uppsala castle in 1567.55 Other examples of this kind include when the society printed longer correspondences between persons, for instance the letters between King Charles XI and Field Marshal von Ascheberg in the fifth and sixth volumes, or the correspondence of the late medieval bishop Hans Brask published in the thirteenth through to the eighteenth volumes. ${ }^{56}$

The question of scholarly editing was also a question of language and translation. At a meeting in July 1818 it was decided that when printing the continuation of the letters between King Charles XI and the Field Marshal Rutger von 
Ascheberg in the sixth volume of Handlingar, only the Swedish translation should be used and not the original German. ${ }^{57}$ In the preceding volume both the original texts and the translations had been published side-by-side, but in the sixth volume it was stated that it was 'tillfyllest att lemna dessa i öfversättning, sedan läsaren ... haft tillräckligt tillfälla att lära känna Konungens styl, och sätt att skrifva tyska' [good enough to leave these (letters) in translation, since the readers ... have had sufficient opportunity to become acquainted with the King's style, and manner of writing in German]..$^{58}$ It seems that the publishers meant that German had to be translated, but that readers could translate the French themselves. The same goes for Latin, which is usually left untranslated, as is Old Norse and medieval Swedish.

\section{The History Told}

In the new understanding of history and historicity that evolved during the later years of the eighteenth century, the ideal of narration and of historical narrative became more and more important in opposition to older, chronicle-based ways of writing history. ${ }^{59}$ This shift is clearly visible in the preface to the first volume of Handlingar. The short programmatic text begins with the statement that:

Om Historien skall uppfylla sin bestämmelse måste hon icke blott vara Krönika; hon måste icke endast uppteckna händleserna, utan tillika söka den naturliga ordning hvari de utgătt ifrån hvarandra, söka de driffjedrar som frambragte eller styrde dem, de orsaker ...

[If History shall fulfill its destiny, she must not be merely a Chronicle; she must not only record the events, but also seek the natural order wherein they have emanated from each other, seek the mainspring that generated or guided them, the reasons ... $]^{60}$

This demand for narration is also shown in the selection of texts to be printed by the society. When the different themed groupings are considered, it becomes clear that they are intended to support a historical narrative. This is underlined by the fact that more than half of the published documents are letters, a kind of document that in itself tells a story. Many of the published letters are also public letters of one sort or another, where the letter writer is trying to explain something to a group of people, for example a letter from King Johan III to 'invånarne i Gudhems och Frökinds Härader om orsakerna till en Riksdags sammankallande m.m.' [the inhabitants of the jurisdictional districts of Gudhem and Frökind explaining the summoning of the Parliament etc.] in the eighteenth volume of Handlingar. ${ }^{61}$

This tendency, and the preface at large, seems to mirror a new - romantic, or modern - sense of history, an idea of history as a process in which you can trace causality and contexts, as opposed to an earlier view of history as a series of object lessons in how to act (or not) in particular circumstances - the Historia Magistra Vitae. As Reinhardt Koselleck explains, this new understanding of history also 
coincides with history becoming a central category of politics during the decades around $1800 .{ }^{62}$ At the same time, modern history became more important, especially if it could be seen as relevant to contemporary politics. ${ }^{63}$ This is clearly visible in the number of documents from the seventeenth and eighteenth centuries which were printed by Kungliga Samfundet during the first twenty years, many of them dealing with events only some seventy years old. This seems to have been an absolute time limit, however: no documents concerning historical events in which the society's members had themselves played a part were printed.

The new sense of history also involved increased interest in individuals and their part in historical events. Apparently this also meant that individuals started to see themselves as historical actors. In the preface to the first volume of Handlingar, one of the reasons for collecting and printing documents from private archives is said to be since 'vår egen tid har bevisat att de handlingar som bära namn af officiella icke äro tillräcklige' [our own time has proved that the documents that bear the name of officials are not sufficient]. ${ }^{64}$ The older generation among the founders of the society - von Engeström, Stjerneld, Adlerbeth, and Silfverstolpe - had all been active as politicians and diplomats since the 1770 s and 1780 s and had witnessed (and in some cases been a part of) the assassination of Gustav III, the French Revolution, the Napoleonic Wars, the deposition of Gustav IV, and the Swedish loss of Finland in 1809. As members of the political opposition in the 1780s, and as actors in the aftermath of the coup d'état of 1809 (where both Adlerbeth and Silfverstolpe were part of the group that wrote the new liberal constitution of 1809), they also had personal knowledge of how official documents do not tell the entire story, but mediate specific parts of it. ${ }^{65}$ Their new historical consciousness, and their sense of themselves as being part of the historical process, is likewise visible in the fact that they very consciously left their notes, letters, and collections to posterity by donating them to different institutions, or created family archives on their estates. Von Engeström, Adlerbeth and Silfverstolpe also wrote autobiographies, another new way to preserve one's memory and mark one's place in history. ${ }^{66}$

If we want to analyse the kind of history which the Kungliga Samfundet wanted to promote, a certain group of documents are especially suitable, namely six documents from the collections of the founder of the society, Adolf Ludvig Stjerneld. These documents were all said to stem from the collections of the poet, historian, and courtier Olof von Dalin (1708-1763) and were all acknowledged as genuine source documents at the time (though since exposed as forgeries, probably written around 1800 by Stjerneld himself) ${ }^{67}$ The documents were presented as transcripts of older originals, most of them were believed to have been written circa 1730-1740, but some seemed to date from the sixteenth century. They all stand out as narrative sources, where an author is telling a story to an audience, rather than being snap shots from a person's life like a letter, or indirectly saying something about society like a court transcript or a protocol. This narrative form, together with their appealing content, has made them highly quotable for historians since their publication. The documents have titles like 'Konung Gus- 
taf Ericssons märkvärdiga yttranden om Sveriges Konung och Svenska Folket, m.m.' [King Gustaf] Ericsson's remarkable opinions about the Swedish King and the Swedish people, etc.]; 'Karakteristik af den Kongliga Gustavianska Familjen' [Characteristics of the royal Gustavian family]; and 'Facta till Revolutions-Historien under Konung Carl XII:s Regering, Drottning Ulrica Eleonoras samt början af Konung Fredrics; med teckning af dihörandepersoners lynnen. Detta af ett åsyna vittne' [Facts relating to the history of the revolution during King Charles XII's, Queen Ulrica Eleonora's and King Fredric's government; with characteristics of various associated persons. This is by an eyewitness]. ${ }^{68}$

Just by looking at these titles one can see how the new sense of history discussed above is present, in the focus on narrative and the eye witness perspective as well as in the idea of 'revolution' and 'facts' ${ }^{69}$ 'Facta till Revolutions-Historien' is the longest text and is worth analysing more thoroughly. The document is a 107-page overview of what happened after the death of Charles XII during the siege of the Norwegian/Danish fortress Fredriksten in 1718. It starts with the construction of Charles XII as an ideal monarch, tough with high officials who had made errors, but kind towards the lower classes and his soldiers and pages. ${ }^{70}$ It also has strong nationalistic tendencies, blaming foreign advisors to kings and politicians for things that have gone wrong, and describing the Swedes as a manly, upright, and honest people with the many virtues of soldiers and knights. ${ }^{71}$

The main agenda of the text, however, is to try to tell the story of what happened after the death of Charles XII, when the king's sister, Ulrica Eleonora the younger, first became queen, followed the next year by her husband Fredrik of Hessen and the rise of the parliamentary rule in Sweden that is known as the 'age of liberty.'72 The author repeatedly claims that he wants to 'find the reason' and 'uncover the mainspring' of the events, meaning that he wants to trace the causality of the events, a causality that he seeks in the actions of individuals, thereby claiming the history to be specific and non-repeatable. ${ }^{73}$ The tendency of the narrative is royalist: the state of the country at the time the text claims to be written (c. 1740) is described as chaotic and lacking in honour and international prestige. The author wants a stronger monarchy, if not the absolutism of Charles XII, then something closer to it, where parliament holds the king in check, but with the king ultimately in charge. As mentioned previously, this is very much in line with the overall tendency of the works of the Royal Society.

\section{Collective Collecting and the Creation of a Patriotic History}

The Kungliga Samfundet worked as a sort of collective collector, where the society's members brought together the documents to be printed from different sources. In this way the society functioned a lot like the German Verenigungs that were founded from the 1820 s onwards. The collective effort of these societies was seen as more secure over longer periods of time than individual collecting. ${ }^{74}$ As with the Kungliga Samfundet, the German counterparts also relied heavily on 
print material - either reprints of documents, descriptions of historical artefacts, or sketches and pictures of objects and monuments.

Although the collecting - the printing of the volumes - was a collective measure where the society and not its individual members were the sender, the individual members also benefited from the printing as every printed document had its provenance thoroughly provided. The contributing members' collections were in this way highlighted as being of national importance and the owner of the document could pose as a servant of public good who generously shared his property for the good of the nation. To underline this even further, the collections (or at least parts thereof) of four of the leading members of the society - Magnus Brahe, Stjerneld, Jacob De La Gardie, and Nils Gyllenstierna - were published in the seventeenth volume. ${ }^{75}$

The composition of the Kungliga Samfundet, and its aim of disseminating historical source documents to a wide audience rather than merely providing historians with working material, positions the society between the eighteenth-century practice of editing for pleasurable reading and the later professionalization, during the nineteenth century, of both history writing and source editing. Like so many other projects of its time, the Kungliga Samfundet was presented as a kind of national monument, inscribed in an inclusive language of patriotism and nation. But as in the case of its built equivalents, whether museums, pantheons, or monuments, it is far from clear whether or not the society actually promoted an emancipatory, nationalist agenda. Rather, and again like the comparable institutions, the nationalist and patriotic meaning of the project was limited. In a study of pantheon projects throughout Europe between the 1790s and 1840, the Dutch historian Eveline Bouwers concludes that these projects, driven by aristocratic politicians stemming from the ancient regime, more often than not offered a 'political discourse intended to preserve an elite's power, consolidate its reputation, and control its legacy. ${ }^{76}$ Given the selection of printed material and the composition of the society during its first twenty years, the same is certainly true for the Kungliga Samfundet. The collective collecting efforts of the society inscribed the aristocratic members' own collections in a nationalist discourse and made them part of the nation's heritage, thereby also guaranteeing the members' social status and the importance of their families.

\section{Conclusion}

Like the museums of the early nineteenth century, the aim of the Kungliga Samfundet was not to serve the scientific or scholarly community, but rather something larger and more political: to be part of the creation of a new patriotic history, based on the new romantic sense of history as connected to nation and people. To serve this notion, the society aimed at printing historical documents that together formed a historical monument. This monument was distributed to what was perceived as a wide circle of subscribers, including all the country's gymnasiums. The documents can be interpreted not only as texts, but as copies 
of objects, with relic-like qualities, something that is underlined by the inclusion of facsimile copies of documents written by kings and other valued historical actors. Viewed in this way, as a product of its time and of an emerging, modern sense of history, the Kungliga Samfundet exemplifies the manifold aspects of the nation making process of post-Napoleonic Europe. Together with museums, monuments, literature, and art, the Kungliga Samfundet and its other European counterparts constructed and negotiated a national history, a memory, and a heritage, which still stands today.

\section{Notes}

1 This article is part of the author's research project 'Creating a Patriotic History', financed by the Swedish Research Council. An earlier version of the article was presented at the conference Collecting Texts and Manuscripts, 1660-1850 held at Plymouth University in 2015 and I would like to thank the organisers and participants in the session for their valuable comments. I am also grateful to Chris Haffenden, Peter Josephson, My Klockar Linder, and Petter Tistedt who have given invaluable input during the process.

2 Unless otherwise indicated, all translations are my own. The committee was later restyled as Kungliga samfundet för utgivande av handskrifter rörande skandinaviens historia (the Royal Society for the printing of documents concerning the history of Scandinavia). See Severin Bergh, Kungliga samfundet för utgifvande af handskrifter rörande skandinaviens historia under första årbundradet af dess tillvaro (Stockholm: Norstedts, 1917), 11. The geographical term 'Scandinavia' was first used in both Danish and Swedish propaganda during the Napoleonic Wars between 1806 and 1814 to legitimate claims to the Swedish throne by the Danes and the annexation of Norway by the Swedes; see 'Fra "Det förenade scandinavien" till "den skandinaviska halfön"; Skandinavistisk propaganda før skandinavismen. 1808-1814', in Skandinavism. En rörelse och en idé under 1800-talet, ed. Magdalena Hillström and Hanne Sanders (Göteborg: Makadam, 2014). Here the use of the term is most probably a comment on the new union between Sweden and Norway in 1814

3 On the role of national museums in the European national state since the late eighteenth century, see for example Peter Aronsson and Gabriella Elgenius, 'Making National Museums in Europe - a Comparative Approach', in Building National Museums in Europe 1750-2010. Conference proceedings from EuNaMus, European National Museums: Identity Politics, the Uses of the Past and the European Citizen, Bologna 28-30 April 2011. EuNaMus Report No 1, ed. Peter Aronsson and Gabriella

Elgenius (Linköping: Linköping University Electronic Press, 2011), 5. Concerning the role of literary editions as the cultural memory of a nation, see for example Ann Rigney, 'Portable Monuments. Literature, Cultural Memory and the Case of Jeanie Deans', Poetics Today 25, no. 2 (2004), 366, doi: 10.1215/03335372-25-2-361.

4 See for example Paula Henriksson and Christian Janss, Geschichte der Edition in Skandinavien. Bausteine zur Geschichte der Edition 4 (Berlin: De Gruyter, 2013); Lotte Jensen, Joep Leerssen, and Marita Mathijsen. ed., Free Access to the Past. Romanticism, Cultural Heritage and the Nation (Leiden: 
Brill, 2010); and Joep Leersen and Dirk van Hulle, eds., Editing the Nation's Memory. Textual Scholarship and Nation-Building in Nineteenth-Century Europe (Amsterdam: Rodopi, 2008).

5 On the popularization of history and its connections to nations and nationalism, see for example Stefan Berger, Chris Lorenz, and Billie Melman, Popularizing National Pasts. 1800 to the present (New York: Routledge, 2012).

6 For a brief overview of the new idea of history around 180o, see for example Peter Burke, Cirka 1808: Restructuring Knowledges/Um 1808: Neuordning der Wissensarten (Munich/Berlin: Art Stock Books, 2008); Reinhardt Koselleck, 'Historia Magistra Vitae: The Dissolution of the Topos into the Perspective of a Modernized Historical Process', in Futures Past. On the Semantics of Historical Time, Reinhardt Koselleck (New York: Columbia University Press, 2004); Mats Persson, 'Upplysningen och historismen: Utsikt över ett forskningsläge', in Lychnos. Årsbok för idé- och lärdomshistoria (Annual of the Swedish History of Science Society, 2000), 59-105.

7 Inrikes Tidningar 139, no. 26 (November 1814).

8 Letter to Charles XIII from A. L. Stjerneld, July 6, 1815. Riksarkivet, Kungliga Samfundet. . arkiv, Räkenskaper 1815-1840.

9 Riksarkivet, Kungliga Samfundet, Räkenskaper 1815-1840. The people that gave more than 10 $\mathrm{Rdr}$ a year were all aristocrats and among the highest ranking officials in the country. Only two people gave 50 Rdr: the Norwegian Prime Minister Peder Anker and count Magnus Fredrik Brahe, head of the Brahe family which was thought to be the highest ranking noble family in Sweden.

10 Herbert Grundmann, Monumenta Germaniae Historica 1819-1969 (München: Monumenta Germaniae Historica, 1969), 1-2.

11 Rolf Torstendahl, Källkritik, 217. There were also similar works being prepared in Sweden during the 1770 s and onwards. The editors were Carl Gustaf Nordin and Eric Michael Fant (who were also involved in Kungliga Samfundet). In 1818 Fant presented the first volume of Scriptores rerum svecicarum medii aevi, a work that was continued in 1828 and 1871-1876 by other editors. In 1829 , Johan Gustaf Liljegren, the Antiquarian of the Realm and secretary of Kungliga Samfundet, published the first volume of Svenskt Diplomatarium (Diplomatarium Suecanum). Svenskt Diplomatiarium was not institutionalised until the 1870 s when it was included in the duties of the National Archive (Riksarkivet), but survived as a private venture of archivist and scholar Bror Emil Hildebrand.

12 On the collective collecting of different societies in the early nineteenth century, see Susan A. Crane, Collecting and Historical Consciousness in Early Nineteenth-Century Germany (Ithaca: Cornell University Press, 2000), 81.

13 Grundmann, Monumenta, 2; David Knowles, 'Presidential address. Great historical enterprises III. The Monumenta Germaniae Historia', Transactions of the Royal Historical Society 5, no. 10 (1960), 130.

14 Rolf Torstendahl, Källkritik och vetenskapssyn i svensk bistorisk forskning 1820-1920 (Uppsala: Svenska bokförl./Norstedts, 1964), 218.

15 R. Arthur Roberts, 'Concerning the Historical Manuscripts Commission', Transactions of the Royal Historical Society 4 (1910).

16 Letter to Charles XIII from A. L. Stjerneld, July 6, 1815. Riksarkivet, Kungliga Samfundet, Räkenskaper 1815-1840.

17 Crane, Collecting, 112. 
18 Ibid., 110.

19 On the use of plaster casts in museums in the nineteenth century century, see for example Francis Haskel and Nicholas Penny, Taste and the Antique (New Haven: Yale University Press: 1981); Solfrid Söderlind, 'En europeisk figur på antik grund' in Söderlind, red., Gips. Tradition $i$ konstens form (Stockholm: Nationalmuseum, 1999); Gunvor Lindström, 'Historismus als Ordnungsprinzip. Die Abgußsamlung im Neuen Museum' and Viola Vahrson, 'Die Krise der Historischen Kunstbetrachtung. Die Berliner Abgußsamlung zwischen Enzyklopädie und Aura', in Musumsinszenierungen. Zur Gescbichte der Institution des Kunstmuseums Der Berlinder Museumslandschaft 1830-1990, ed. Alexis Joachimides et al. (Dresden and Basel: Verlag der Kunst, 1995).

20 Letter to Charles XIII from A. L. Stjerneld, July 6, 1815. Riksarkivet, Kungliga Samfundet, Räkenskaper $1815^{-1840 .}$

21 On the role of statistics and what the term meant in a Swedish context during the period, see for example Henrik Höjer, Svenska siffror: nationell integration och identifikation genom statistik $1800-$ 1870 (Hedemora: Gidlunds, 2001).

22 Crane, Collecting, 91

23 Letter to Charles XIII from A. L. Stjerneld, July 6, 1815. Riksarkivet, Kungliga Samfundet, Räkenskaper 1815-1840.

24 Answer from Charles XIII, July 12, 1815, backside of Letter to Charles XIII from A. L. Stjerneld, July 6, 1815. Riksarkivet, Kungliga Samfundet, Räkenskaper 1815-1840. The full (and very short) answer reads: 'Med upsträckta händer underskrifver jag det Project till att förskaffa fler upplysning uti sitt Fäderneslands historia och skall efter mitt tillstånd gifva en Summa att beleda denna inrättning' [With my arms raised I endorse this project to provide more people with information about the history of their fatherland, and I will after my permission give a sum to support this institution].

25 Günter Oesterle, 'The conception of popularity in the enlightenment and romanticism', Romantik. Journal for the Study of Romanticisms 2, (2013): 44-7, doi: 10.7146/rom.v211.20192.

26 Ibid., 46.

27 Joep Leerssen, 'Notes towards a definition of romantic nationalism', Romantik. Journal for the study of romanticisms 2 (2013), 23, doi: 10.7146/rom.v211.20191.

28 Preface to Handlingar rörande Skandinaviens Historia. Tolfte delen (Stockholm, 1825).

29 Preface to Handlingar rörande Skandinaviens Historia. Första delen (Stockholm, 1816).

30 Protocol, December 14, 1816, Riksarkivet, Kungliga Samfundet, Protokoller 1815-1840.

31 See for example the letter from King Charles X to the admiral of the realm Carl Gustaf Wrangel in vol. 4 that was given both as facsimile and transcribed as part of a series of letters in the volume. Handlingar rörande Skandinaviens Historia. Fjerde delen (Stockholm, 1817), 277, and facsimile at the end.

32 The protocol specifies that they want the volumes to be printed in a 'large octave' format, which is similar in size to a quarto volume, but presumably cheaper to produce. Protocol, November 10, 1815, Riksarkivet, Kungliga Samfundet, Protokoller 1815-1840.

33 Protocol, July 7, 1818, Riksarkivet, Kungliga Samfundet, Protokoller 1815-1840.

34 Protocol, November 10, 1815, Riksarkivet, Kungliga Samfundet, Protokoller 1815-1840.

35 Protocol, July 8, 1816, Riksarkivet, Kungliga Samfundet, Protokoller 1815-1840. 
36 Answer to letter to Charles XIII from A. L. Stjerneld, July 6, 1815. Riksarkivet, Kungliga Samfundet, Räkenskaper 1815-1840. The entire one-sentence answer reads: 'Med upsträckta händer underskrifver jag det Project till att förskaffa fler upplysning uti sitt Fäderneslands historia och skall efter mitt tillstånd gifva en Summa att beleda denna inrättning' [With my arms raised I endorse this project to provide more people with information about the history of their fatherland, and I will after my permission give a sum to support this institution].

37 The catalogued collections belonged to Magnus Brahe (part of the Skokloster entail), Adolf Ludvig Stjerneld (made into an entail that should be donated to Uppsala University after the death of the last male descendant of the baronial family Stjerneld), Jakob de la Gardie (at Löberöd mansion), and Nils Gyllenstierna (part of the Krapperup entail). All four catalogues were printed as a supplement to the seventeenth volume (1832). (The limitations of the survey are due to my larger research project, where A. L. Stjerneld serves as a prism for a study of heritage making, use of history, and history popularisation in the early nineteenth century. The nineteenth volume was the last that involved Stjerneld in its production as he died in 1835 . The twentieth volume begins with a short biography of him as the founder of the society.)

38 Concerning the first quotation of this sentence, see for example Handlingar rörande Skandinaviens Historia. Tredje delen (1817) and Sjunde delen (1825). Concerning the second quotation, see for example Handlingar rörande Skandinaviens Historia. Tolfte delen (1825). Concerning the last quotation, see Handlingar rörande Skandinaviens Historia. Fjerde delen (1817).

39 Protocol, March 15, 1816, Riksarkivet, Kungliga Samfundet, Protokoller 1815-1840.

40 Protocol, June 10, 1820, Riksarkivet, Kungliga Samfundet, Protokoller 1815-1840.

41 Letter from A. L. Stjerneld to L. von Engeström, undated (1816), Kungliga biblioteket, Ep. E 10:18, 300 .

42 The letters from Stjerneld to Engeström can be found in Engeström's correspondence, now in the royal library, Kungliga biblioteket, volumes Ep. E 10:17-23. Letters to Stjerneld have not been found in any archives.

43 See for example Protocol, November 29, 1817, Riksarkivet, Kungliga Samfundet, Protokoller $1815-1840$

44 Protocol, October 27, 1821, Riksarkivet, Kungliga Samfundet, Protokoller 1815-1840.

45 Appendix to protocol, October 27, 1821, Riksarkivet, Kungliga Samfundet, Protokoller 1815-1840.

46 Appendix to protocol, October 27, 1821, Riksarkivet, Kungliga Samfundet, Protokoller 1815-1840.

47 Handlingar rörande Skandinaviens Historia. Nionde delen (Stockholm, 1821), Preface.

48 On the National Portrait Gallery, see for example Per Widén, 'Meritorious Citizens in Royal Surroundings: The National Portrait Gallery of Sweden and its use of a Historical Environment as Exhibition Space', Museum History Journal 8, no. 1 (2015): 73-87, doi: 10.1179/1936981614Z.oooo 0000041 .

49 Emil Hildebrand, 'Svenska publikationer af historiska handlingar', Historisk tidskrift, Sjette årgången (Stockholm, 1886): 353

5o On Törneros, Palmblad, and classical philology in Sweden at the time, see Bo Lindberg, Humanism och vetenskap. Den klassiska filologien i Sverige frän 1800-talets början till andra världskriget Lychnos bibliotek 36 (Uppsala, Lärdomshistoriska samfundet 1987), 123-42.

51 Lindberg, Humanism och vetenskap, 101. 
52 The committee laments this in the preface to the first volume, and asks for information concerning interesting documents in private collections as well as in the different gymnasium libraries. Handlingar rörande Skandinaviens Historia. Första delen (Stockholm, 1816).

53 Handlingar rörande Skandinaviens Historia. Andra delen, 153-218 and 219-97. For the Rising of the Dalesmen, see Sennefelt, Karin, Den politiska sjukan: Dalupproret 1743 och fribetstida politisk kultur (Uppsala/Hedemora, Gidlunds 2001)

54 Handlingar rörande Skandinaviens Historia. Tredje delen, 205-50 and 251-70.

55 Handlingar rörande Skandinaviens Historia. Fjerde delen, 55-226.

56 Handlingar rörande Skandinaviens Historia. Femte delen, 262-312, Handlingar rörande Skandinaviens Historia. Sjette delen, 57-80. Handlingar rörande Skandinaviens Historia. Trettonde delen, 17-134, Fjortonde delen, 25-95, Femtonde delen, 4-50, Sextonde delen, 7-130, Sjuttonde delen, 67-224, and Adertonde delen, 211-346.

57 Protocol, July 7, 1818, Riksarkivet, Kungliga Samfundet, Protokoller 1815-1840

58 Handlingar rörande Skandinaviens Historia. Sjette delen, 59.

59 Persson, 'Upplysningen och historismen', 71.

6o Handlingar rörande Skandinaviens Historia. Första delen (Stockholm, 1816).

61 'K. Johan III:s Skrifvelse till invånarne i Gudhems och Frökinds Härader om orsakerna till en Riksdags sammankallande m.m.', in Handlingar rörande Skandinaviens Historia, Adertonde delen (Stockholm, 1833), 356ff.

62 Koselleck, 'Historia Magistra Vitae', 26-42. For an overview of the new view of history, see Persson, 'Upplysningen och historismen' and Burke, Circa 1808/Um 1808.

63 Persson, 'Upplysningen och historismen', 64.

64 Preface to Handlingar rörande skandinaveiens historia. Första delen (Stockholm, 1816).

65 On their roles and careers in politics, see respective articles in Svenskt biografiskt lexikon:

'Gudmund Jöran Adlerbeth', 'Lars von Engeström', 'Axel Gabriel Silverstolpe', and 'Adolf Ludvig Stjerneld'.

66 Gudmund Jöran Adlerbeth's archive and autobiographical notes were left to Uppsala University Library by his son and part of them has been printed, e.g. a manuscript about the political history of Sweden 1789-1809 entitled Historiska anteckningar (Historical annotations) that was published in three volumes 1856-1857 and a second time in two volumes 1892-1893, as well as his diary from Gustav III's journey to Italy in 1783-1784, Svenska memoarer och bref. 5, Gustaf III:s resa i Italien: anteckningar af Gudm. Göran Adlerbeth in 1902. Lars von Engeström's autobiography was printed as Minnen (Memories) in 1876 and his letters are preserved at the National Library. Axel Gabriel Silfverstolpe's archive with letters and autobiographical notes were preserved in the family archive at the mansion of Näs, now in the National Archives. Adolf Ludvig Stjerneld donated his collections to Uppsala university library, but does not seem to have written any autobiographical notes, nor did he donate his correspondence.

67 Paul Sjögren, 'Erland Hjärne om Adolf Ludvig Stierneld som historieförfalskare. Efterlämnande handlingar i Uppsala universitetsbibliotek', Nordisk tidskrift för bok- och biblioteksväsen (1980): 67. See also Widén, 'Stierneld, Adolf Ludvig'.

68 'Konung Gustaf Ericssons märkvärdiga yttranden om Sveriges Konung och Svenska Folket, m.m.', in Handlingar rörande Skandinaviens Historia. Första delen (Stockholm, 1816), 'Karakteristik af den Kongliga Gustavianska Familjen', in Handlingar rörande Skandinaviens Historia. Första delen (Stockholm, 1816), 'Facta till Revolutions-Historien under Konung Carl XII:s 
Regerign, Drottning Ulrica Eleonoras samt början af Konung Fredrics; $d$ teckning af diverse dihörande[sic!] personers lynnen. Detta af ett åsyna vittne', in Handlingar rörande Skandinaviens Historia. Sjunde delen (Stockholm, 1819). For a list of all of Stjerneld's forgeries published by the society, see the bibliography in Widén, 'Stierneld, Adolf Ludvig'.

69 See for example Koselleck, 'Historical Criteria of the Modern Concept of Revolution' in Koselleck's Futures Past.

70 See for example 'Facta till Revolutions-Historien ...', 199 n.

71 'Facta till Revolutions-Historien', 205, 230, 237, 263, 221 and 225.

72 For an overview, see Michael Roberts, The Age of Liberty. Sweden 1719-1772 (Cambridge: Cambridge University Press, 1986)

73 'Facta till Revolutions-Historien', 191 and 220.

74 Crane, Collecting, 81ff.

75 Handlingar rörande Skandinaviens historia 17 (Stockholm, 1832).

76 Eveline G. Bouwers, Public Pantheons in Revolutionary Europe. Comparing Cultures of Remembrance, c. 1790-1840 (Basingstoke: Palgrave Macmillan 2012), 4-11. For a similar (and connected) Swedish example, see Widén, 'Meritorious Citizens in Royal Surroundings'. 